\title{
Of the Labyrinth: becoming worldly with darkness
}

\section{TROLLCIRKLAR}

\begin{abstract}
"In Finland, the Lapp hunters and shepherds would walk the labyrinths to protect themselves from wolves and wolverines and to entrap the trolls and other evil spirits, who would follow them in, but would be unable to find their own way out... from the centre of the labyrinth".
\end{abstract}

http://www.labyrinthos.net/centre.html

\begin{abstract}
A darkness experiment in a forest near Nokia, Finland in November 2015; and my notable absentpresence - is a serious fiction. The experiment holds together contradictions, synergies and tensions through processes of gathering and archiving which facilitate encounters with the "other" (both real and imaginary: biomedicine, labyrinth/itis, trolls, wolverines and darkness). It is an ongoing, generative attempt to nurture nourishing alliances that transform research practices. Working with new materialist theorists, the experiment pushes us to think "through the co-constitutive materiality of human corporeality and nonhuman natures" (Alaimo \& Hekman, 2008:9); it provides tools: figurations, metaphors, and narratives to identify and work with alternative creative onto-ethical-epistemologies to those readily employed in educational research.
\end{abstract}

\section{labyrinth (n.)}

c. 1400, laberynthe (late 14c. in Latinate form laborintus) "labyrinth, maze," figuratively "bewildering arguments," from Latin labyrinthus, from Greek labyrinthos "maze, large building with intricate passages," especially the structure built by Daedelus to hold the Minotaur near Knossos in Crete, from a pre-Greek language; perhaps related to Lydian labrys "double-edged axe," symbol of royal power, which fits with the theory that the labyrinth was originally the royal Minoan palace on Crete and meant "palace of the double-axe." Used in English for "maze" early 15c., and in figurative sense of "confusing state of affairs" (1540s).

http://www.etymonline.com/index.php?term=labyrinth 
The experiment embraces rhizomatic thinking and nomadic subjectivities because it involves taking up performative new materialist methodologies, through practices of wandering/wondering, gathering, sharing, grappling and curating. Such practices require a different logic, an engagement with and attentiveness to sinuous processes and practices. Sharing sounds, images, stories and figures gathered through doing and thinking a performative experiment allows for a focus on the patterns created and the traces left by the multiple complex figurative entities (including labyrinthing, string figuring, darkness) encountered and the wandering/wondering throughout spacetimematter. The types of stories created and told from the darkness/forest experiment draw attention to ways of being, ways of knowing, and ways of becoming together that disrupt, transmogrify, revitalize, and generate other ways.

\begin{abstract}
"The labyrinth incorporates the peripheral sensory organs for balance and hearing, in a delicate membranous network (incorporating the utricle, saccule, semi-circular canals and cochlea)". http://patient.info/doctor/labyrinthitis
\end{abstract}

The surest way to experience the labyrinth's intricate pathway and feel the cunning blend of concealment and revelation is the path always seeming to take you to the centre, only then to swing back out again, suddenly finds you standing at the centre, unsure how you arrived - is to go and walk, or run, one of the ancient labyrinths that still exist".

http://www.labyrinthos.net/labyrinthstory.html

As Alaimo \& Hekman (2008: 12-13] urge, we might work with Haraway's stories to be reminded that our understanding of nature should incorporate historically located people, other organisms and technological artefacts. "Nature" must encompass demarcation and continuity among actors that are both human and nonhuman, organic and inorganic. The practice of otherworldly conversations in which various nonhuman entities participate as subjects rather than objects - provides one model for ethical relations that respect difference and allow for mutual transformation. Or in the words of Haraway herself:

"We must find another relationship to nature besides reification, possession, appropriation, and nostalgia. No longer able to sustain the fictions of being either subjects or objects, all the partners in the potent conversations that constitute nature must find a new ground for making meanings together." (Haraway, 2008:158 in Alaimo \& Hekman) 


\author{
Minotaur: \\ hybrid man-beast \\ of woman born \\ nursing mother \\ becoming monster \\ savaged and ate humans \\ saved from execution \\ hidden in the labyrinth...
}

The Minotaur signifies, unsettles and fascinates. Monstrous monsters signify thereby making them central to folk tales, myths, and legends. Signification: what it means, who makes-meaning, why meaning is made, and how it is made, what meanings do, what we do with the affects of those meanings - should be our concern not the horror of the monstrous itself. In the "Promises of Monsters" Haraway (2004) offers a mapping exercise and travelogue through mindscapes and landscapes of what may count as local/global struggles. The purpose of the exercise is to write theory: 'to produce a patterned vision of how to move and what to fear in the topography of an impossible but-all-too-real present, in order to find an absent, but possible, other present' (p.63). The optical features of Haraway's theory produce effects of connection, of embodiment, and a responsibility for an imagined elsewhere that can be detected and built.

\begin{abstract}
Among the Hopi of northern Arizona, the Labyrinth is depicted in two forms. One known as Tápu'at (Mother and Child), has a subtle reconnection of the lines to produce one labyrinth within another, the Mother Earth symbol depicting the unborn child within the womb of its mother and cradled in her arms after birth.
\end{abstract}

http://www.labyrinthos.net/centre.html

The forest/darkness experiment responds to some of Haraway's (1997, 2004, 2008) invitations to untangle a ball of yarn: pull out the threads, follow the actors, loosen the knots through affective, bodily, worldly experiments.

The analyst is always already

in a cathetic relationship to the object of analysis

and $\mathrm{s} /$ he needs to excavate the implication of this bond 
of her/his being in this world

in this way rather than some other.

Articulating the analytical object,

figuring,

for example,

this family or kinship of entities,

chip,

gene,

foetus,

bomb, etc

(it is an indefinite list)

is about location and historical specificity,

and it is about a kind of assemblage,

a kind of connectedness to the figure and the subject."

(Haraway, 2004: 338) 


\section{References}

Alaimo, S. \& S. Hekman (Eds) (2008). Material Feminisms. (pp. 157-187). Indiana:

University Press.

Deleuze, G. (1994). Difference and repetition. (P. Patton, Trans.) New York: Columbia University Press.

Deleuze, G., \& Guattari, F. (1987). A thousand plateaus: Capitalism and schizophrenia (B. Massumi, Trans. 2004 ed.). London: Continuum (Originally published as Milles Plateaux, volume 2 Capitalisme et Schizophénie, 1980).

Haraway, D. J. (2002). The persistence of vision. In N. Mirzoeff (Ed.), The visual culture reader (pp. 677-684). London: Routledge.

Haraway, D.J. (1994). 'A Game of Cat's Cradle: Science Studies, Feminist Theory, Cultural Studies', Configurations 2(1), 59-71.

Haraway, D.J. (2004). The Haraway Reader. (pp. 63-124). London: Routledge.

Haraway, D.J. (2008) 'Otherworldly Conversations, Terran Topics, Local Terms' in S. Alaimo \& S. Hekman (Eds) Material Feminisms. (pp. 157-187). Indiana: University Press.

Saward, J. (2016). The centre of the Labyrinth. Retrieved from http://www.labyrinthos.net/centre.html

Saward, J. (2016). The story of the labyrinth. Retrieved from http://www.labyrinthos.net/labyrinthstory.html 